\title{
Momordica charantia L. Fruit Fractions inhibit Malondialdehyde Level and Regenerate Hepatic Damage of Hyperglycemic Rats
}

\author{
Parawansah $^{1, *}$, I Putu Sudayasa ${ }^{2}$, Andi Noor Kholidha Syarifin ${ }^{3}$, Amirudin Eso $^{4}$, Nuralifah $^{5}$, \\ Wa Ode Siti Rahayu Fathanah ${ }^{6}$, Ferry Sandra ${ }^{7}$ \\ ${ }^{1}$ Department of Pharmacology, Faculty of Medicine, Universitas Halu Oleo, Jl. HEA Mokodompit, Kendari, Indonesia \\ ${ }^{2}$ Department of Public Health and Community Medicine, Faculty of Medicine, Universitas Halu Oleo, Jl. HEA Mokodompit, \\ Kendari, Indonesia \\ ${ }^{3}$ Department of Biochemistry and Molecular Biology, Faculty of Medicine, Universitas Halu Oleo, Jl. HEA Mokodompit, Kendari, Indonesia \\ ${ }^{4}$ Department of Anatomy, Faculty of Medicine, Universitas Halu Oleo, Jl. HEA Mokodompit, Kendari, Indonesia \\ ${ }^{5}$ Department of Pharmacology, Faculty of Pharmacy, Universitas Halu Oleo, Jl. HEA Mokodompit, Kendari, Indonesia \\ ${ }^{6}$ Medical Program Study, Faculty of Medicine, Universitas Halu Oleo, Jl. HEA Mokodompit, Kendari, Indonesia \\ ${ }^{7}$ Department of Biochemistry and Molecular Biology, Division of Oral Biology, Faculty of Dentistry, Universitas Trisakti, J1. Kyai Tapa No.260, \\ Jakarta, Indonesia \\ *Corresponding author. E-mail: parawansah_biom@yahoo.co.id
}

Received date: Aug 8, 2019; Revised date: Dec 2, 2019; Accepted date: Dec 17, 2019

\section{Abstract}

B ACKGROUND: Chronic hyperglycemia causes an increase of free radical production and in longterm, the hyperglycemia increases oxidative stress. Among medicinal plants, Momordica charantia L. fruit has been known to overcome hyperglycemia. However, role of $M$. charantia $\mathrm{L}$. fruit on oxidative stress is not well understood. Therefore, current study was conducted to investigate the effect of $M$. charantia $\mathrm{L}$. fruit extract on malondialdehyde (MDA) level and hepatic damage in hyperglicemic rat model.

METHODS: Twenty five white rats (Rattus novergicus) were induced with Streptozotocin (STZ) and treated with/ without glibenclamide, sodium carboxymethyl cellulose (Na-CMC), or M. charantia L. fruit ethanol/ethyl acetate/ n-hexane fraction. After the treatment, rat's livers were collected and separated for histopathological examination and MDA analysis.

RESULTS: The MDA level average of rats before the STZ induction was $1.37 \mu \mathrm{g} / \mathrm{mL}$. MDA level average was markedly increased $(23.85 \mu \mathrm{g} / \mathrm{mL})$ in rats induced with STZ and treated with Na-CMC merely. The MDA level average of STZ-induced glibenclamide-treated rats was $3.12 \mu \mathrm{g} / \mathrm{mL}$. Meanwhile, the MDA level averages of STZ-induced M. charantia L. fruit ethanol, ethyl acetate and $n$-hexane fractions-treated rats were $14.95,8.98$ and $5.37 \mu \mathrm{g} / \mathrm{mL}$, respectively. The histopathology results of this study showed that adipocytes, dilated sinusoids and central vein thickening were mostly observed in STZ-induced NaCMC-treated rats. Meanwhile, the STZ-induced ethanol/ ethyl acetate/n-hexane fraction-treated rats did not exhibit those expressions.

CONCLUSION: $M$. charantia $\mathrm{L}$. fruit fractions inhibit the MDA level average in liver tissue and regenerate hepatic damage of STZ-induced rats, especially the n-hexane fraction which could be a potential hepatic antioxidant and regenerative agent.

KEYWORDS: Momordica charantia L., malondialdehyde, oxidative stress, hyperglycemia, diabetes mellitus

Indones Biomed J. 2020; 12(1): 57-61 


\section{Introduction}

Diabetes mellitus (DM) is one of metabolic diseases with hyperglycemia due to the abnormality of pancreatic $\beta$ cell insulin secretion, insulin resistance or both.(1,2) According to the International Diabetes Federation (IDF) in 2019, there were 463 million adults, aged 20-79 years old, diagonised with DM, in the world.(3) This represented $9.3 \%$ of world's population in this age group. In Indonesia, there were 10.7 million adults with DM. Indonesia was included in the top 10 countries for number of adults (20-79 years) with DM in 2019.

The chronic hyperglycemia causes an increase in free radical production. Reactive Oxygen Species (ROS) are group of free radicals, reactive molecules, and ions derived from $\mathrm{O}_{2}$.(4) Free radicals initiate membrane lipid peroxidation and produce malondialdehyde (MDA). (5) When the produced free radical can't be countered by endogenous antioxidant systems, the oxidative stress condition will be occured.(6,7) Severe oxidative stress can cause pancreatic $\beta$ cell damage, which can decrease its function.

MDA has been used as a biomarker of lipid peroxidation and oxidative stress.(8-10) MDA levels, the end product of lipid peroxidation in certain tissues, are considered as a marker of oxidative stress in certain tissues, while MDA levels in plasma and urine represent oxidative stress throughout the body.(11)

The increasing of oxidative stress can contribute to complications of DM, both microvascular and macrovascular.(12) Microvascular complications include retinopathy, nephropathy, and neuropathy, while the macrovascular complications can lead to cardiovascular diseases.(13) Complications of DM greatly affect the quality of life so that they need to get appropriate treatment and serious attention.(14)

Some medicinal plants and their products are important therapeutic choices to relieve DM symptoms. Among all the medicinal plants, Momordica charantia L. fruit has been known to be able to overcome hyperglycemia. The active ingredient of the fruit which is a hypoglycemic agent, among others, is charantin. $(15,16)$ However, the role of $M$. charantia L. fruit on oxidative stress is still not well understood. Therefore, current study was conducted to investigate the effect of $M$. charantia L. fruit extract on MDA level and hepatic damage in hyperglicemic rat model.

\section{Methods}

\section{Extraction and Fractionation}

Fifteen $\mathrm{kg}$ of $M$. charantia L. fruits were dried, macerated with 96\% methanol and evaporated. Resulted thick extract of $M$. charantia L. fruit was extracted with ethanol, ethyl acetate, and n-hexane to divide the polarity of the compound. The extraction was done by liquid-liquid fractionation using a separating funnel.

\section{Animal Model, Treatment and Sample Collection}

Twenty five white rats (Rattus novergicus) with the body weight of 150-250 grams were acclimatized for 7 days. Hyperglicemic induction was carried out by giving 40 $\mathrm{mg} / \mathrm{kg}$ BW Streptozotocin (STZ) (Cayman Chemical Company, Ann Arbor, MI, USA). Blood glucose levels of rats were measured using a glucometer (EasyTouch Glucose Monitoring System, MHC Medical, Fairfield, $\mathrm{OH}$, USA) before and after the STZ induction subcutaneously. The induced rats were divided into 5 treatment groups. Group 1 (positive control): treatment with $0.09 \mathrm{mg} / \mathrm{kg}$ BW/day glibenclamide (Indofarma, Bekasi, Indonesia); Group 2 (negative control): treatment with $0.5 \%$ sodium carboxymethyl cellulose (Na-CMC)/day (Cayman Chemical Company); Group 3: treatment with $400 \mathrm{mg} / \mathrm{kg}$ BW $M$. charantia L. fruit ethanol fraction/day; Group 4: treatment with $400 \mathrm{mg} / \mathrm{kg} \mathrm{BW}$ M. charantia L. fruit ethyl acetate fraction/day; and Group 5: treatment with $400 \mathrm{mg} / \mathrm{kg} \mathrm{BW/}$ day $M$. charantia L. fruit $\mathrm{n}$-hexane fraction. Treatments were performed by using feeding tubes. After 7 days of treatment, the rat was euthanized with chloroform. Rat's livers were collected and separated, the right lobe was fixed with $10 \%$ formalin for histopathological examination, and the left lobe was used for MDA analysis. The protocol of this study was reviewed and approved by Research Ethical Committee of LPPM Universitas Halu Oleo (No. 2033/ UN29.20/PPM/2018).

\section{MDA Analysis}

One hundred $\mathrm{mg}$ of each left lobe was crushed and homogenized in $500 \mu \mathrm{L}$ distilled water. The homogenate was centrifuged and resulted supernatant was collected. One hundred $\mu \mathrm{L}$ of the supernatant was mixed with $550 \mu \mathrm{L}$ of distilled water, $100 \mu \mathrm{L}$ of $4 \%$ Trichloroacetic Acid (TCA) (Merck, Darmstadt, Germany), $250 \mu \mathrm{L}$ of $1 \mathrm{~N} \mathrm{HCl}$ (Merck) and $100 \mu \mathrm{L}$ of $1 \%$ Thiobarbituric Acid (TBA) (Merck). The mixture was incubated in an oven at $95^{\circ} \mathrm{C}$ for $15 \mathrm{~min}$, 
then centrifuged at room temperature. Supernatant was collected and measured at the wavelength of $532 \mathrm{~nm}$ using UV-visible spectrophotometer (Bio-Rad, Hercules, CA, USA) and plotted on a standard curve to calculate sample concentration. The standard curve was prepared using an MDA standard solution (Sigma-Aldrich, St. Louis, MO. USA).

\section{Histopathology Slide}

The $24 \mathrm{~h}$-fixed right lobe issues were paraffinized and sliced in $6 \mu \mathrm{m}$. The tissue sections were then de-paraffinized and stained with Hematoxylin and Eosin (HE). HE-stained slides were analyzed and examined by an anatomic pathologist.

\section{Results}

\section{STZ-induced Blood Glucose Level of Rats}

Blood glucose level averages of rats before and 1-day-after the STZ induction were $88.64 \mathrm{mg} / \mathrm{dL}$ and $290.56 \mathrm{mg} / \mathrm{dL}$, respectively. Besides the increment of blood glucose level, STZ induction also caused polydipsia, polyuria, polyphagia.

\section{M. charantia L. Fruit Ethanol, Ethyl Acetate and n-hexane Fractions inhibited STZ-induced MDA Level}

By using MDA standard solution, a standard curve was resulted, $\mathrm{y}=0.0185 \mathrm{x}+0.0925$. MDA level average before the STZ induction was $1.37 \mu \mathrm{g} / \mathrm{mL}$. MDA level average of Group 2 was $23.85 \mu \mathrm{g} / \mathrm{mL}$ (Figure 1). These results indicated that STZ increased free radical as indicated by the MDA. MDA level average of Group 1 was $3.12 \mu \mathrm{g} /$ $\mathrm{mL}$, indicating that the glibenclamide inhibited the MDA level of STZ-induced rats. MDA level averages of Group 3, 4 and 5 were significantly lower than the average of Group 2 (ANOVA test, $p=0.000$ ). Among Group 3, 4 and 5 , the Group 5 showed the lowest MDA level average. The MDA level average of Group 5 did not show a significant difference with the MDA level average of Group 1, as the positive control ( $\mathrm{T}$ test, $p=0.207$ ).

\section{Hepatic Histopathology}

Hepatic histopathology of STZ-induced rats with/without treatment of $M$. charantia L. fruit fractions was shown in Figure 2. Adipocytes were mostly observed in Group 2 (Figure 2B). Besides adipocytes, dilated sinusoids and central vein thickening were also observed in Group 2 . Some adipocytes were also observed in Group 3 (Figure $2 \mathrm{C}$ ), meanwhile only few adipocytes were observed in Group 1, 4 and 5.

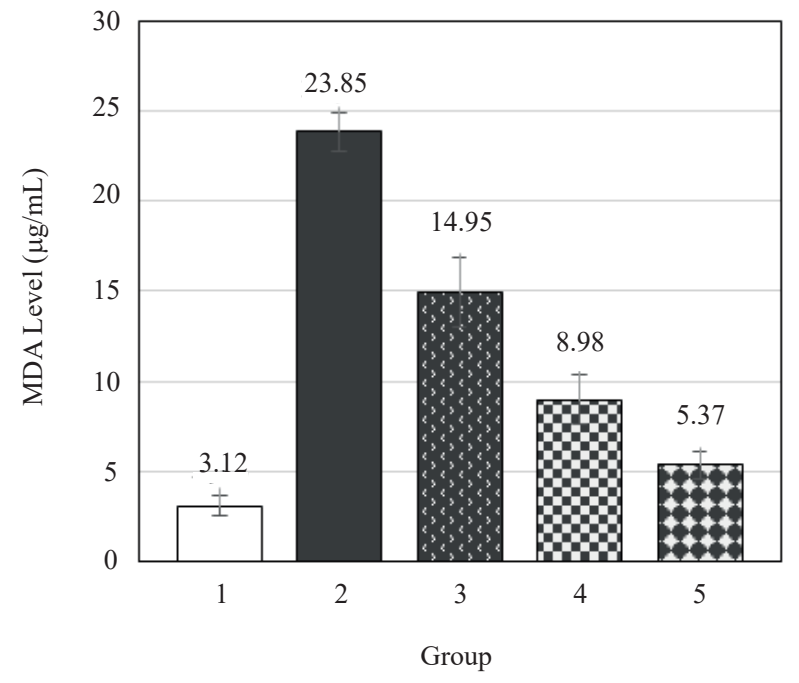

Figure 1. MDA level averages of STZ-induced rats with/ without treatment of $M$. charantia $L$. fruit fractions. Group 1: STZ-induced rats were treated with glibenclamide; Group 2: NACMC; Group 3: $M$. charantia L. fruit ethanol fraction; Group 4: $M$. charantia L. fruit ethyl acetate fraction; Group 5: M. charantia L. fruit n-hexane fraction. Rat's livers were collected, separated, and processed for MDA analysis according to the Methods.

\section{Discussion}

MDA level average of Group 2 was increased, suggesting that $40 \mathrm{mg} / \mathrm{kg}$ BW STZ induced oxidative stress, which is in accordance to the previous report.(17) STZ induction causes the formation of free radicals, such as superoxide $\left(\mathrm{O}_{2}^{-}\right)$, hydrogen peroxide $\left(\mathrm{H}_{2} \mathrm{O}_{2}\right)$, hydroxyl $\left(\mathrm{OH}^{-}\right)$and others. During hyperglycemia, the glucose autooxidation, protein glycation, and polyol metabolic pathway will be activated, which eventually accelerate the formation of reactive oxygen.(18)

MDA level average of Group 1 almost approached the MDA level average of the rat before the STZ induction. glibenclamide as a positive control, successfully reduced the MDA level. These findings indicate that glibenclamide showed an anti-peroxidative effect thought to be related with hypoglycemic effects.(19)

MDA level average of Group 3 was lower than the one of Group 2. These results could be supported by the antioxidant content of $M$. charantia $\mathrm{L}$. fruit ethanol fraction, drawn by polar solvent like steroid saponins known as charantin. $(20,21)$ Charantin increases glucose uptake and glycogen synthesis in the liver, muscle, and adipose tissue cells. Charantin accelerates the process of glucose uptake, as well as the synthesis of glycogen in the liver, muscles, 

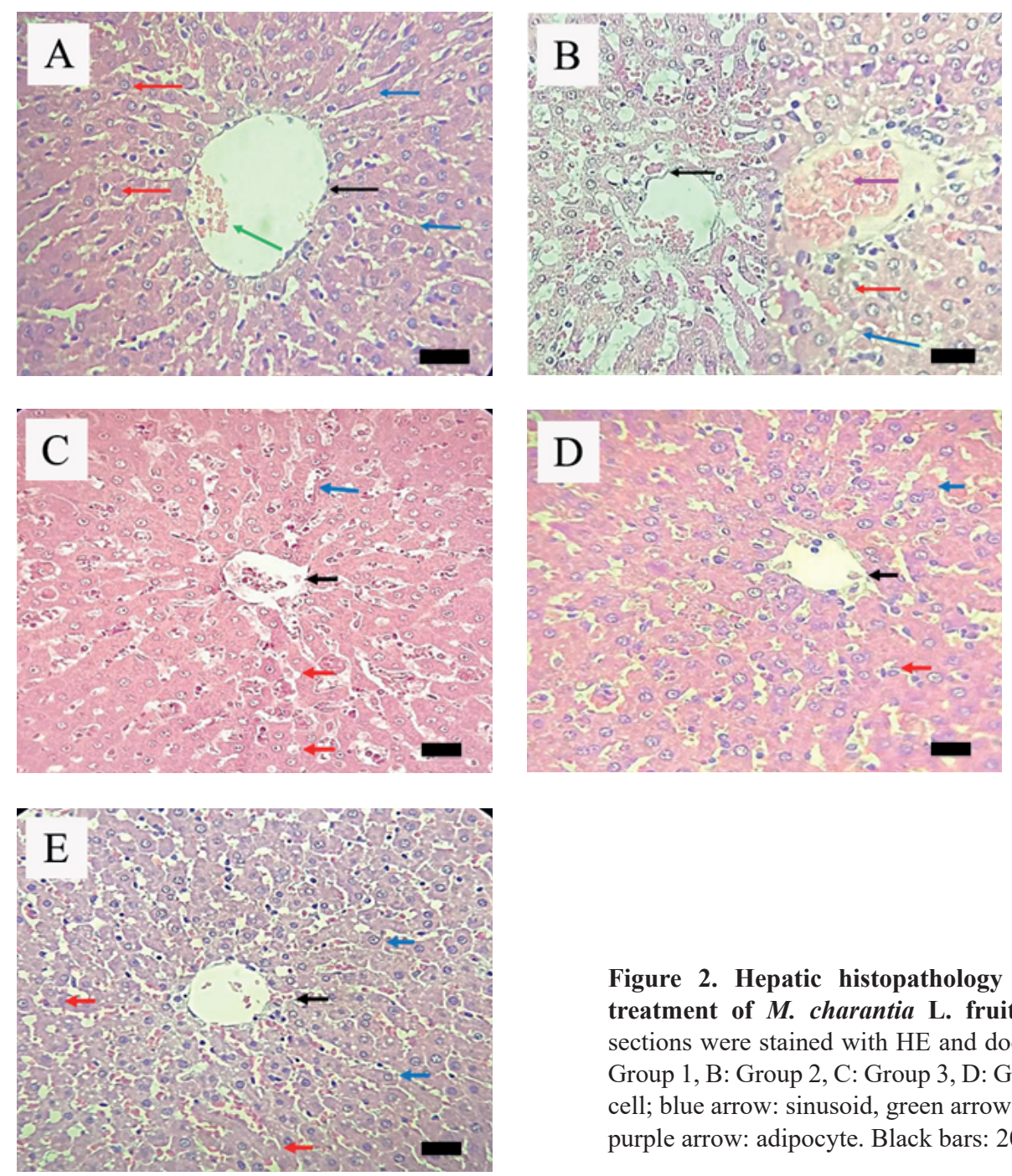

Figure 2. Hepatic histopathology of STZ-induced rats with/without treatment of $\boldsymbol{M}$. charantia L. fruit fractions. Hepatic right lobe tissue sections were stained with $\mathrm{HE}$ and documented under a light microscope. A: Group 1, B: Group 2, C: Group 3, D: Group 4 and E: Group 5. Red arrow: liver cell; blue arrow: sinusoid, green arrow: erythrocyte, black arrow: central vein. purple arrow: adipocyte. Black bars: $20 \mu \mathrm{m}$.

and adipocytes. In addition, charantin stimulates pancreatic $\beta$ cells to produce more insulin as well as increases the deposit of glycogen in liver.(22) Flavonoids, exogenous antioxidants containing phenolic groups, have been shown to be useful in preventing cell damage due to oxidative stress. The mechanism of flavonoids as antioxidants is by donating $\mathrm{H}$ atoms to stabilize free radicals.(23)

Based on previous research, non-polar compounds of $M$. charantia L. fruit n-hexane fractions are terpenoid derivatives, namely cucurbits triterpenes.(24) Some of these compounds were Momordin I and Momordin II.

Histopathological results of Group showed normal liver cells, a large number of reddish granular cytoplasm, dilated blood vessels containing erythrocytes and blood vessel walls without hyaline (Figure 2A). These results indicate improvement after glibenclamide treatment. These results showed that glibenclamide as an anti-diabetes drug can repair or regenerate hepatic damage.
In Group 2 (Figure 2B), there were fat degeneration, sinusoidal dilation, and central vein thickening. Fat degeneration was damaged in hepatocytes characterized by morphological changes and decreased the function of the liver due to fat accumulation in the liver cell cytoplasm. Fat degeneration is characterized by vacuoles containing fat and pushing the nucleus to the edge of the cell. Sinusoid dilatation is characterized by widening of the capillary liver which may involve the entire lobule or is mostly in the middle, periportal, or medial region. This result is in line with the previous report (25), which showed that STZinduced rat livers experienced fatty, widening veins and sinusoids.

Treatment of $M$. charantia L. fruit ethanol, ethyl acetate, and N-hexane fractions showed liver polygonal cells with a normal ratio of nucleus and cytoplasm. In addition, the results showed many granular and reddish cytoplasm and also dilated blood vessels containing erythrocytes. The 
walls of blood vessels with hyaline were thin and there was no thickening of the arteries. There were few adipocytes were observed and sinusoids were not dilation. These results indicate that there is an improvement in liver tissue within the normal range after being treated with $M$. charantia $\mathrm{L}$. fruit fractions. The tissue repair was related to the administration of $M$. charantia L. fruit fractions which have antioxidant content and their potential in reducing blood glucose levels. The M. charantia L. fruit n-hexane fraction (Group 5) was an effective fraction indicated by a significant decrease in MDA levels, which was not significantly different from the group treated with the glibenclamide group (Group 1) and there was liver tissue improvement within normal range after being given the fraction. Due to its effectiveness in decreasing MDA levels, the content isolation of $M$. charantia $\mathrm{L}$. fruit $\mathrm{n}$-hexane fraction should be pursued.

\section{Conclusion}

M. charantia L. fruit fractions inhibit the MDA level average in liver tissue and regenerate hepatic damage of STZ-induced rats, especially the n-hexane fraction which could be a potential hepatic antioxidant and regenerative agent.

\section{References}

1. Widowati W, Maesaroh, Fauziah N, Erawijantari PP, Sandra F. Free Radical Scavenging and $\alpha$-/ $\beta$-glucosidase Inhibitory Activities of Rambutan (Nephelium lappaceum L.) Peel Extract. Indones Biomed J. 2015; 7: 157-62.

2. Hamuaty RB, Sukmawati IR, Sandra F. Relationship between sRAGE and hsCRP as Markers of Cardiovascular Disease Risk Factors in Diabetic and Non-Diabetic Men with Central Obesity. Mol Cell Biomed Sci. 2017; 1: 70-4.

3. International Diabetes Federation. IDF Diabetes Atlas. 9th ed. [internet]. Brussels: International Diabetes Federation; 2019. [cited: 2019 Nov 27]. Available at: http://www.diabetesatlas.org.

4. Sharma P, Jha AB, Dubey RS, Pessarakli M. Reactive Oxygen Species, Oxidative Damage, and Antioxidative Defense Mechanism in Plants under Stressful Conditions. J Botany. 2012; 2012: 217037.

5. Goudu AS, Naidu MD, Pradesh A. Effect of Fluoride on Oxidative Stress and Biochemical Markers of Bone Turnover in Postmenopausal Women. Fluoride. 2013; 46: 208-11.

6. Sheikhpour R. Diabetes and Oxidative Stress: The Mechanism and Action. Iranian J Diabetes Obesity. 2013; 5: 40-5.

7. Singh UN, Kumar S, Dhakal S. Study of Oxidative Stress in Hypercholesterolemia. Int J Contemp Med Res. 2017; 4: 1204-7.

8. Tangvarasittichai S, Poonsub P, Tangvarasittichai O, Sirigulsatien V. Serum Levels of Malondialdehyde in Type 2 Diabetes Mellitus Thai
Subjects. Siriraj Med J. 2009; 6: 20-3.

9. Grotto D, Maria LS, Valentini J, Paniz C, Schmitt G, Garcia S, et al. Importance of The Lipid Peroxidation Biomarkers and Methodological Aspects for Malondialdehyde Quantification. Quim. Nova. 2009; 32: 169-74.

10. Parawansah, Nuralifah, Alam G, Natzir R. Inhibition of Xanthine Oxidase Activity by Ethanolic Extract of Piperomia pellucids L., Acalypha indica L., and Momordica charantia L. Indones Biomed J. 2016; 8: 161-6.

11. Weitner $\mathrm{T}$, Inić $\mathrm{S}$, Jablan $\mathrm{J}$, Gabričević $\mathrm{M}$, Domijan $\mathrm{AM}$. Spectrophotometric Determination of Malondialdehyde in Urine Suitable for Epidemiological Studies. Croat Chem Acta. 2016; 89: 133-9.

12. Jalees SS, Rosaline M. Study of Malondialdehyde and Estimation of Blood Glucose Levels in Patients with Diabetes Mellitus with Cataract. Int J Clin Biochem Res. 2017; 4: 319-23.

13. Forbes JM, Cooper ME. Mechanisms of Diabetic Complications. Physiol Rev. 2013; 93: 137-88.

14. American Diabetes Association. Microvascular Complications and Foot Care: Standards of Medical Care in Diabetes 2018. Diabetes Care. 2018; 41: S105-18.

15. Efird JT, Choi YM, Davies SW, Mehra S, Anderson EJ, Katunga LA. Potential for Improved Glycemic Control with Dietary Momordica charantia L. in Patients with Insulin Resistance and Pre-Diabetes. Int J Environ Res Public Health. 2014; 11: 2328-45.

16. Joseph B, Jini D. Antidiabetic Effects of Momordica charantia (Bitter melon) and Its Medicinal Potency. Asian Pac J Trop Dis. 2013; 3: 93-102.

17. Pinheiro L, de Melo AD, Andreazzi AE, de Caires Júnior LC, Costa MB, Garcia RMG. Protocol of Insulin Therapy for StreptozotocinDiabetic Rats Based on a Study of Food Ingestion and Glycemic Variation. Scand J Lab Anim Sci. 2011; 38: 117-27.

18. Szkudelski T. The Mechanism of Alloxan and Streptozotocin Action in $\beta$ Cells of the Rat Pancreas. Physiol. Res. 2001; 50: 537-46.

19. Erejuwa OO, Sulaiman SA, Wahab MSA, Salam SK, Salleh MS, Gurtu S. Comparison of Antioxidant Effects of Honey, Glibenclamide, Metformin, and Their Combinations in the Kidneys of Streptozotocin-Induced Diabetic Rats. Int J Mol Sci. 2011; 12: $829-43$.

20. Singh SR, Hijam D, Dubey A, Devi NO, Jamir S, Longkumer C, et al. Study of Oxidative Stress Status in Type 2 Diabetic Patients. Int J Contemp Med Res. 2015; 2: 20-6.

21. Nagappan, Krishnaveni., Anoop, Karthika, Kowmudi, Gullapalli, Sailaja, Mukkamala. Charantin: A Neglected Antidiabetic Compound from Momordica charantia L. Int J Pharm Sci Rev Res. 2018; 51: 35-40.

22. Altinterim B. Bitter Melon (Momordica charantia) and the Effects of Diabetes Disease. J Agricultur Fac Uludag Univ. 2012; 26: 65-9.

23. Parawansah, Nurtamin T, Mulyawati SA, Nuralifah, Misnaeni, WOA. Immunomodulatory Effect of Momordica charantia L. Fruit Ethanol Extract on Phagocytic Activity and Capacity of Mice Peritoneal Macrophages. Indones Biomed J. 2018; 10: 144-7.

24. Arsad SS, Esa NM, Hamzah H. Histopathologic Changes in Liver and Kidney Tissues from Male Sprague Dawley Rats Treated with Rhaphidophora decursiva (Roxb.) Schott Extract. J Cytol Histol. 2014; S4: 001.

25. Zafar M, Naeem-Ul-Hassan Naqvi S, Ahmed M, Kaimkhani ZA. Altered Liver Morphology and Enzymes in Streptozotocin Induced Diabetic Rats. Int J Morphol. 2009; 27: 719-25. 